\title{
The effect of premilking udder preparation on Holstein cows milked 3 times daily
}

\author{
R. D. Watters, ${ }^{\star}$ N. Schuring, † H. N. Erb, $¥$ Y. H. Schukken, $§$ and D. M. Galton ${ }^{\star 1}$ \\ *Department of Animal Science, College of Agriculture and Life Sciences, Cornell University, Ithaca, NY 14853 \\ †GEA Farm Technologies, Naperville, IL 60563 \\ ¥Section of Epidemiology, Department of Population Medicine and Diagnostic Sciences, and \\ $\S$ Quality Milk Production Services, Department of Population Medicine and Diagnostic Sciences, College of Veterinary Medicine, \\ Cornell University, Ithaca, NY14853
}

\begin{abstract}
Premilking udder preparation (including forestripping and duration of lag time - the time between first tactile stimulation and attachment of milking unit) might influence milking measures such as milking unit on-time, incidence of bimodality, and milk flow rates in Holstein cows milked 3 times daily. Holstein cows $(\mathrm{n}=786)$ from an 1,800-cow commercial dairy herd were enrolled under a restricted randomized design to determine the effect of 9 different premilking routines. Lag times were $0,60,90,120$, and $240 \mathrm{~s}$ and included forestripping or no forestripping for a total of 9 treatments (no forestripping for 0 lag time); the study was conducted from February to November 2008. All cow-treatment combinations were compared with the control: predipping plus forestripping and drying with $90 \mathrm{~s}$ of lag time. Cows were initially assigned to 1 of 3 treatments for a period of $7 \mathrm{~d}$ and upon completion of the first 7-d period were reassigned to a different treatment until all treatments had been completed. From one treatment period to the next, cows had to switch stimulation method with no restriction on lag time. Cows did not receive all treatments during the duration of the trial. Early- to mid-lactation cows (EML; 17-167 DIM) and late-lactation cows (LL; 174-428 DIM) were housed in 2 different pens. Milk yield was significantly different between dip + forestrip and dip + dry for 2 of the treatments for EML cows compared with dip + forestrip and $90 \mathrm{~s}$ of lag-time (DF90); however, this was not thought to be due to treatment because the significant lag times were very different (60 and $240 \mathrm{~s}$ ) and neither was an extreme value. Milk yield did not differ with treatment for the LL cows. Milking unit on-time did not differ when comparing all treatments for EML with treatment DF90; however, an increase in milking unit on-time occurred when lag time was $60 \mathrm{~s}$ or less for
\end{abstract}

Received March 23, 2011.

Accepted November 16, 2011.

${ }^{1}$ Corresponding author: dmg20@cornell.edu
LL cows. The highest incidence of bimodal milk curves was when lag time $=0$ and this was independent of stage of lactation; a lag time of $240 \mathrm{~s}$ had the secondhighest incidence of bimodal milk curves for EML and LL cows. Milk harvested in the first 2 min was lower for lag times of 0 and $240 \mathrm{~s}$ when compared with DF90. Increasing the lag time for all cows appeared to improve overall milking time efficiency (although lag time had no effect on EML cows).

Key words: premilking routine, udder preparation, lag time, bimodality

\section{INTRODUCTION}

The premilking routine is typically performed manually, and variation in the premilking routine from person-to-person and day-to-day is common. The premilking routine consists of many components designed to improve overall milk quality, proper milk letdown, mammary health, and milking-time efficiency. The premilking routine can involve sanitation of the teat, forestripping, drying, and timing of milking-unit attachment. Many factors (e.g., breed of cow, stimulation method, stage of lactation, and timing of milking-unit attachment) affect milking-time variables. Immediately attaching the milking unit will allow for the harvest of the cisternal milk fraction, which amounts to $20 \%$ of the milk volume in the udder. The remaining $80 \%$ is alveolar milk that is not readily available for milk harvest until activation of the milk-ejection reflex (Bruckmaier and Blum, 1996, 1998). A form of tactile stimulation and proper prep-lag times are required to harvest the alveolar milk fraction, which is under the control of a neuroendocrine mechanism involving the release of oxytocin (Bruckmaier and Blum, 1996). Prep-lag time is defined as the time from when the first form of tactile stimulation (either forestripping or drying) is administered until milking-unit attachment. The release of oxytocin and its subsequent binding to receptors on myoepithelial cells leads to the expulsion of the alveolar milk fraction. 
A summary of studies from the past $30 \mathrm{yr}$ indicated that stimulation of at least $20 \mathrm{~s}$ and a total prep-lag time of $60 \mathrm{~s}$ reduced milking unit on-time and increased the average flow rate compared with no stimulation (Reneau and Chastain, 1995). Those studies were performed on cows that were milked twice daily, were crossbred cattle, or had levels of milk production that were lower than today's higher yielding cows. Weiss and Bruckmaier (2005) indicated that a short prestimulation time would increase the cows per milking stall with cows that had a high degree of udder filling and that prolonged stimulation might be beneficial when milking cows with a low degree of udder fill. Decreasing the time spent on the premilking routine also improves cow throughput (cows/milking stall) and increases capital investment (Smith et al., 2005). The latter approach spreads the investment out over more cows and increases the return on investment.

Much of the focus historically has been placed on milk yield and milking unit on-time as the key variables of interest. More recently (with advancements in milk flow-meter technology), the ability to measure milk-flow curve characteristics more accurately has increased. The incidence of bimodal milk curves and percentage of milk harvested in the first $2 \mathrm{~min}$ are newer parameters to evaluate milking routines. A recent study of Italian Holstein-Friesian cattle found that $35 \%$ of milk flow curves were bimodal (which suggests poor premilking routines; Sandrucci et al., 2007). Automated milking of cows has the ability to measure milk flow characteristics at the level of the quarter and not the udder. Automated milking systems allow for the analysis of milking characteristics at the level of the quarter, and Bava et al. (2005) reported no difference in the incidence of quarter-level bimodal milk curves for 3 milking intervals $(3.2,1.1$, and $2.2 \%$ for milking intervals of $<9$ $\mathrm{h}, 9-11 \mathrm{~h}$, and $>11 \mathrm{~h}$, respectively).

Our objective was to determine the effect of the premilking routine (which included forestripping, lag time, and their interaction) on milk yield, milking unit ontime, and milk-flow characteristics of high-producing Holstein cows in a commercial herd with various DIM and milked 3 times daily.

\section{MATERIALS AND METHODS}

\section{Cows and Treatments}

Holstein cows $(\mathrm{n}=786)$ from a 1,800 -cow commercial dairy herd were enrolled in a restricted randomized design, such that cows had to switch method of stimulation from one period to the next but not lag time. Cows were housed in a 6-row freestall barn and bedded with a combination of kiln-dried sawdust and drywall gypsum. Cows were fed a TMR that met or exceeded the NRC requirements (NRC, 2001). The $305-d$ mature-equivalent yield of the herd was 13,378 $\mathrm{kg} /$ lactation with a median lactation number of 2 . Cows were milked 3 times daily on a 50-bail rotary parlor. Cows had milking intervals of $8 \mathrm{~h}$ and were milked at 0800, 1600, and $2400 \mathrm{~h}$. The experiment was conducted from February through November of 2008. Early- to mid-lactation cows (EML; 17-167 DIM) and late-lactation cows (LL; 174-428 DIM) were housed in separate pens for the study. Pen size was 200 and 220 cows for EML and LL cows, respectively. All cows had to be $\leq 400$ DIM at the time of enrollment in the study. All cows had to have 4 functioning quarters and could not have had a case of clinical mastitis during the current lactation. The treatments involved 2 forms of stimulation and 5 lag times. The stimulation methods were predipping plus drying $(\mathbf{D})$ and predipping plus forestripping and drying (DF). Forestripping required the removal of 2 streams of milk from each teat. Cloth towels were used for drying of the teats. Application of predip, forestripping, drying, and attachment of the shortest lag times during each period was performed by milkers from the dairy, whereas undergraduate research workers attached milking units to the cows with the longest 2 lag times during each period. All milkers went through a milker training routine prior to the start of the experiment, and the experimental milking protocol was located in the milking center. Lag time was timed from first form of tactile stimulation (either forestripping or drying) and continued until milking-unit attachment and was $0,60,90,120$, or $240 \mathrm{~s}$. This resulted in 9 total treatments: D0, D60, D90, D120, D240, DF60, DF90, DF120, and DF240 (there was no DF0 treatment because it was not possible to have immediate attachment with no stimulation; Table 1). Cows were randomly assigned via computer-generated list to 1 of 3 treatments initially. Cows were balanced for milk yield, unit on-time, milk yield in the first $2 \mathrm{~min}$, DIM, and parity. A treatment lasted for $7 \mathrm{~d}$ with the first 3 d (9 milkings), representing an adaption period and the last $4 \mathrm{~d}$ (12 milkings), representing the data collection period, and the study took place between February and November 2008). A maximum of 3 treatments were administered during any period. Upon completion of a 1-wk period, cows were reassigned to another treatment but had to switch method of stimulation from one period to the next. There was no restriction on lag time other than a cow never repeated the same treatment combination (no cows received all 9 treatments). A mutual agreement was reached before the initiation of the experiment as to the level of participation required by the producer; thus, an informed-consent agreement was reached between the dairy producer and Cornell 
Table 1. Within-trial treatments

\begin{tabular}{lll}
\hline Lag $(\mathrm{s})$ & $\begin{array}{l}\text { Dip }+ \\
\text { Dry (D) }\end{array}$ & $\begin{array}{l}\text { Dip }+ \\
\text { Forestrip (DF) }\end{array}$ \\
\hline 0 & D0 & \\
60 & D60 & DF60 \\
90 & D90 & DF90 \\
120 & D120 & DF120 \\
240 & D240 & DF240 \\
\hline
\end{tabular}

University. Cornell University's Institutional Animal Care and Use Committee approved the experimental protocol.

Cows were identified by leg bands that indicated which lag time and stimulation method they were to receive. Consistent lag time was achieved by starting a stopwatch at first tactile stimulation of the cow and then attaching it to the stall that the cow occupied on the rotary parlor. Parlor operators pressed the start button for milking-unit attachment when the stop watch read $5 \mathrm{~s}$ less than the indicated lag time for the given treatment.

\section{Milking Equipment}

Cows were milked 3 times daily on a 50-bail rotary parlor (GEA Farm Technologies, Bönen, Germany). The milking system had a vacuum setting of $50 \mathrm{kPa}$, pulsation rate of 60 cycles/min, and ratio of $65: 35$. The milking claw had a volume of $300 \mathrm{~mL}$ (Classic 300, GEA Farm Technologies) and was used with a silicone liner that had a collapse force of $33 \mathrm{kPa}$ (Tri-Circle Silicone Liner, Lauren AgriSystems, New Philadelphia, OH).

\section{Data Acquisition}

During both the adaptation and data-collection phases, cow and milking data were gathered on-farm by herd-management software (DairyComp 305, Valley Agricultural Software, Tulare, CA; DairyPlan C21, GEA Farm Technologies).

\section{Statistical Analysis}

Separate statistical analyses were performed for EML and LL cows. Milking parameters measured were milk yield, milking unit on-time, incidence of bimodal milk curves, percentage of total milk yield harvested in the first 2 min of unit on-time, and average flow rate. Results are reported as least squares means \pm standard error of the means (LSM \pm SEM; SAS Institute, 1999) unless otherwise noted. Data were analyzed as repeated measures utilizing the Proc Mixed procedure. The model used to analyze the experiment was

$$
\mathrm{Y}_{\mathrm{ijk}}=\mu+\mathrm{M}+\mathrm{D}_{\mathrm{i}}+\mathrm{S}_{\mathrm{j}}+\mathrm{L}_{\mathrm{k}}+\mathrm{S}_{\mathrm{j}} \times \mathrm{L}_{\mathrm{k}}+\mathrm{Re}_{\mathrm{ijk}},
$$

where $Y_{\mathrm{ijk}}=$ variable of interest, $\mu=$ overall mean, $\mathrm{M}_{\mathrm{i}}$ $=$ milk yield, $\mathrm{D}_{\mathrm{i}}=$ days in milk (1 to 2$), \mathrm{S}_{\mathrm{j}}=$ method of stimulation (1 to 2 ), $\mathrm{L}_{\mathrm{k}}=$ lag time (1 to 5 ), $\mathrm{S}_{\mathrm{j}} \times \mathrm{L}_{\mathrm{k}}=$ interaction of stimulation and lag time, $\mathrm{R}=$ correlation matrix in the error term, correcting for repeated effect of cow within treatment, and $\mathrm{e}_{\mathrm{ijk}}=$ random error. The correlation structure in the repeated-measures effect that was used in the model was compound symmetry. The variables of interest were milking unit on-time, percentage of milk harvested in the first $2 \mathrm{~min}$, and average milk flow rate. Bimodal milk curves were analyzed using Proc Freq (chi-squared) methodology in SAS (SAS Institute, 1999). Significant differences were declared at $P<0.05$.

\section{RESULTS AND DISCUSSION}

Pretrial data were gathered for milk yield, milking unit on-time, milk yield in the first 2 min, average flow rate, DIM, and lactation number (Table 2). In total, 817 cows were assigned to the trial and 786 were used for analysis. Of 31 cows that left the study, 16 cows were from the EML group and 15 were from the LL group. Cows were removed for mastitis $(\mathrm{n}=14$; EML $=9$ and $\mathrm{LL}=5)$, feet and legs $(\mathrm{n}=5 ; \mathrm{EML}=2$ and $\mathrm{LL}=3)$, ketosis $(\mathrm{n}=3 ; \mathrm{EML}=3)$, teat injury $(\mathrm{n}=2$; $\mathrm{EML}=1$ and $\mathrm{LL}=1)$, loss of electronic identification $(\mathrm{n}=2 ; \mathrm{LL}=2)$, oxytocin injection $(\mathrm{n}=1 ; \mathrm{EML}=1)$, and other $(\mathrm{n}=4 ; \mathrm{LL}=4)$.

Mean milk production per milking for DF90 was 16.7 \pm 0.3 for EML and $10.4 \pm 0.3$ for LL during the trial (Table 3). A significant stimulation by lag time interaction was observed for milk yield $(P<0.001)$. The differences in milk yield were not thought to be due to treatment because the lag times were so different $(60$ and $240 \mathrm{~s}$ ) between the treatments that differed from DF90 and yet were not seemingly part of consistent trends. Sagi et al. (1980) found no difference in milk yield when comparing no stimulation, manual stimulation, manual stimulation with lag time of $30 \mathrm{~min}$, and a treatment involving the injection of oxytocin in cows between mo 3 and 5 of lactation. Our data for EML cows agree with their study. Wagner and Ruegg (2002) found no difference in milk yield for Holstein cows milked twice daily when comparing cows that were forestripped or not and independent of stage of lactation. In contrast to our results, Rasmussen et al. (1992) found a tendency for a decrease in milk yield for Holstein cows when lag time was 3 min compared with a lag time $\leq 1.3 \mathrm{~min}$, regardless of stage of lactation. Tancin et al. (2007) determined that a prep-lag time 
Table 2. Pretrial data for cows assigned to treatments ${ }^{1}$

\begin{tabular}{|c|c|c|c|c|}
\hline \multirow[b]{2}{*}{ Variable } & \multicolumn{2}{|c|}{ EML } & \multicolumn{2}{|c|}{ LL } \\
\hline & Mean & $\mathrm{SE}$ & Mean & $\mathrm{SE}$ \\
\hline $\mathrm{N}\left(\right.$ analysis $^{2}$ & 397 & & 389 & \\
\hline $\mathrm{N}(\text { assigned })^{2}$ & 413 & & 404 & \\
\hline Milk yield (kg/milking) & 16.3 & 0.04 & 12.4 & 0.03 \\
\hline Milking unit on-time (s) & 284 & 0.6 & 247 & 0.8 \\
\hline Proportion of milk in first 2 min of on-time (\%) & 50.5 & 0.2 & 55.4 & 0.3 \\
\hline Average flow $(\mathrm{kg} / \mathrm{min})$ & 3.8 & 0.02 & 3.2 & 0.03 \\
\hline Parity & 2.9 & 0.03 & 2.9 & 0.04 \\
\hline DIM & 80 & 0.4 & 270 & 0.7 \\
\hline
\end{tabular}

totaling $60 \mathrm{~s}$ did not increase milk yield compared with a prep-lag time of $10 \mathrm{~s}(2.8 \pm 0.9 \mathrm{~kg})$.

The mean milking unit on-time for DF90 was $279 \pm$ $4.7 \mathrm{~s}$ and $236 \pm 3.8 \mathrm{~s}$ for EML and LL, respectively. Ontime for EML cows did not differ for all treatments $(P$ $=0.22$ ) when compared with DF90; however, on-time for LL cows was longer $(P<0.01)$ than that of DF90 for lag times of $\leq 60 \mathrm{~s}$ (Figure 1). In contrast, Sandrucci et al. (2007) found the shortest on-time when lag times were between 1 and 60 s. Gorewit and Gassman (1985) found that on-time decreased when stimulation time was increased from no stimulation to $15,30,60$, and $120 \mathrm{~s}$ of stimulation; however, they did not account for the interaction between increasing stimulation time and the resultant increase in lag time. As lactation progressed beyond $24 \mathrm{wk}$, Merrill et al. (1987) indicated that milking unit on-time decreased when comparing a full premilking routine $(60 \mathrm{~s})$ to a minimal premilking routine $(15 \mathrm{~s})$, which agrees with our data for EML cows.

The incidence of bimodal milk curves differed from DF90 for all but 2 treatments $(P<0.05)$ for EML cows and for all but 3 treatments for LL cows (Table 4). A significant stimulation by lag time interaction $(P$ $<0.001$ ) was observed for incidence of bimodal milk curves. A recent field study analyzing $>2,400$ milk-flow curves from 82 Italian Holstein-Friesian cows indicated that $35.1 \%$ of milk curves were bimodal and found a significant decrease in the incidence of bimodal milk curves as lag time was increased (Sandrucci et al., 2007). Italian Friesian cows milked in an automated milking system were divided into 3 categories based on time since previous milking, and no difference was observed in the percentage of quarter-level bimodal milk curves for the 3 categories $(3.2,1.1$, and 2.2 for milking intervals of $<9 \mathrm{~h}, 9-11 \mathrm{~h}$, and $>11 \mathrm{~h}$, respectively; Bava et al., 2005). A bimodal milk curve is an indicator of an improper milk routine; however, the effect of bimodal milk curves on udder health is unknown. Dodenhoff et al. (1999) found that a higher electrical conductivity of milk (6.7 vs. $6.3 \mathrm{mS} / \mathrm{cm}$ ) and linear score (3.5 vs. 3.2$)$ were associated $(P<0.001)$ with a higher incidence of bimodal milk curves but the time sequence (the change in conductivity preceding the increased incidence of bimodal curves or vice versa) was unknown.

The percentage of milk harvested in the first $2 \mathrm{~min}$ for DF90 was $51.0 \pm 1.4 \%$ and $61.6 \pm 1.8 \%$ for EML and LL cows, respectively. For EML cows, most treatments did not differ from DF90; however, for LL cows, all but 2 treatments differed from DF90 (Table 5). A significant stimulation by lag time interaction $(P<$ 0.001) was observed for percentage of milk harvested

Table 3.Within-trial milk yield (kg/milking) $)^{1,2}$

\begin{tabular}{|c|c|c|c|c|}
\hline \multirow[b]{2}{*}{ Lag (s) } & \multicolumn{2}{|c|}{ EML $(P<0.001)$} & \multicolumn{2}{|c|}{$\operatorname{LL}(P=0.21)$} \\
\hline & Dip + Dry & Dip + Forestrip & Dip + Dry & Dip + Forestrip \\
\hline 0 & 16.7 & & 10.7 & \\
\hline 60 & 16.0 & $15.1^{\mathrm{a}}$ & 10.6 & 10.6 \\
\hline 90 & 16.9 & 16.7 & 10.7 & 10.4 \\
\hline 120 & 16.0 & 15.9 & 10.2 & 10.7 \\
\hline 240 & 16.3 & $15.2^{\mathrm{a}}$ & 10.2 & 10.9 \\
\hline
\end{tabular}


WATTERS ET AL.

Table 4. Incidence of bimodal milk curves in early to mid (EML) and late lactation (LL) cows

\begin{tabular}{|c|c|c|c|c|}
\hline \multirow{2}{*}{$\begin{array}{l}\text { Group } \\
\text { and lag (s) }\end{array}$} & \multicolumn{2}{|c|}{ Dip + Dry } & \multicolumn{2}{|c|}{ Dip + Forestrip } \\
\hline & Total $^{1}$ & Bimodal (\%) & Total & Bimodal (\%) \\
\hline \multicolumn{5}{|l|}{$\mathrm{EML}^{2}$} \\
\hline 0 & 1,261 & $22^{\mathrm{a}}$ & & \\
\hline 60 & 496 & $9^{\mathrm{a}}$ & 487 & $9^{\mathrm{a}}$ \\
\hline 90 & 560 & $3^{\mathrm{a}}$ & 658 & 5 \\
\hline 120 & 1,142 & $8^{\mathrm{a}}$ & 1,114 & 6 \\
\hline 240 & 585 & $13^{\mathrm{a}}$ & 662 & $13^{\mathrm{a}}$ \\
\hline \multicolumn{5}{|l|}{$\mathrm{LL}^{2}$} \\
\hline 0 & 1,035 & $29^{\mathrm{a}}$ & & \\
\hline 60 & 422 & 9 & 493 & 7 \\
\hline $90^{*}$ & 516 & $18^{\mathrm{a}}$ & 457 & 6 \\
\hline $120^{*}$ & 994 & $15^{\mathrm{a}}$ & 995 & 8 \\
\hline 240 & 487 & $26^{\mathrm{a}}$ & 604 & $20^{\mathrm{a}}$ \\
\hline
\end{tabular}

${ }^{a} P<0.05$ compared with dip + forestrip and $90 \mathrm{~s}$ of lag time (DF90).

${ }^{1}$ Total number of milk curves for each treatment.

${ }^{2} \mathrm{EM}$ and LL differed at $P<0.001$ compared with DF90.

*Comparisons made within row differ at $P<0.05$.

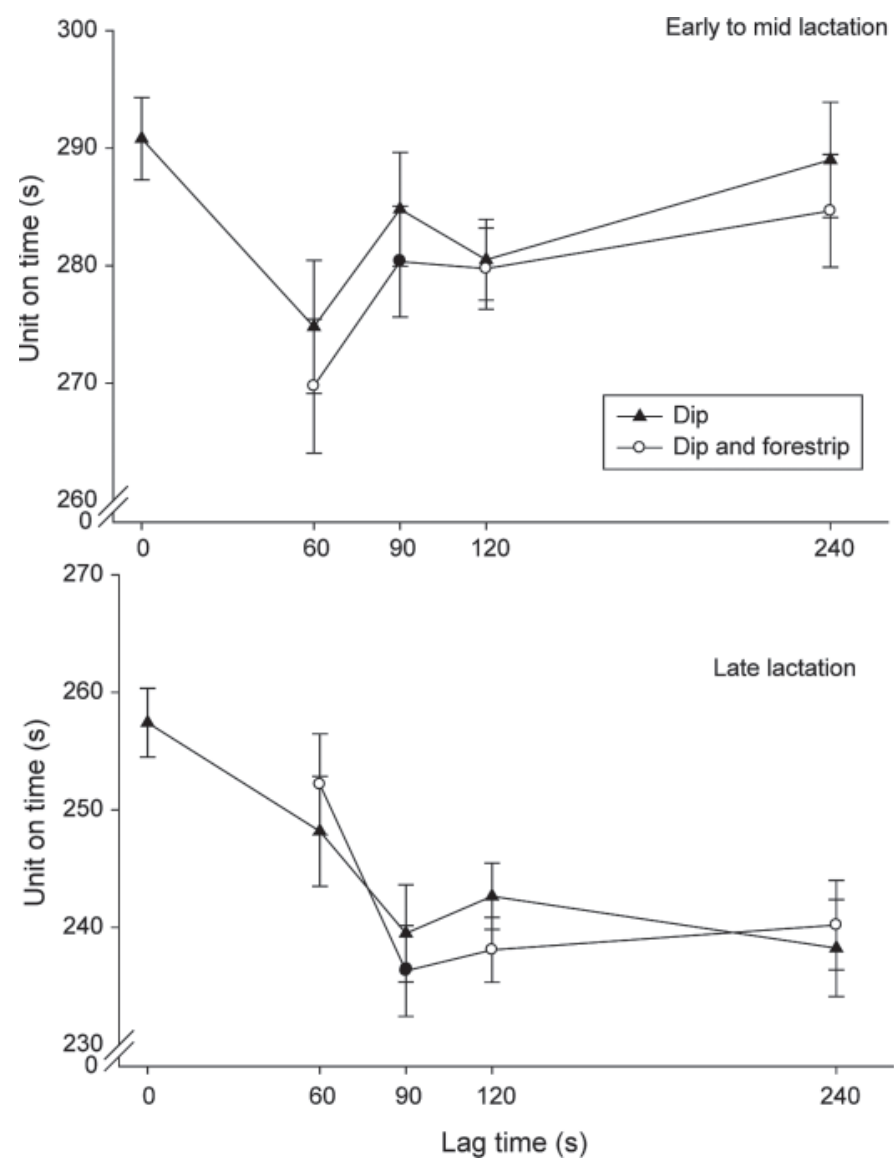

Figure 1. Milking unit on-time (s) for cows following a preparation procedure that involved predipping plus drying $(\mathrm{D}, \mathbf{\Delta})$ or predipping plus forestripping and drying (DF, O) with the comparison treatment (a preparation procedure involving predipping plus forestripping and drying with a lag time of $90 \mathrm{~s}($ DF90, $)$ for early to mid lactation cows (EML); and late-lactation (LL) cows. ${ }^{*} P<0.05$.
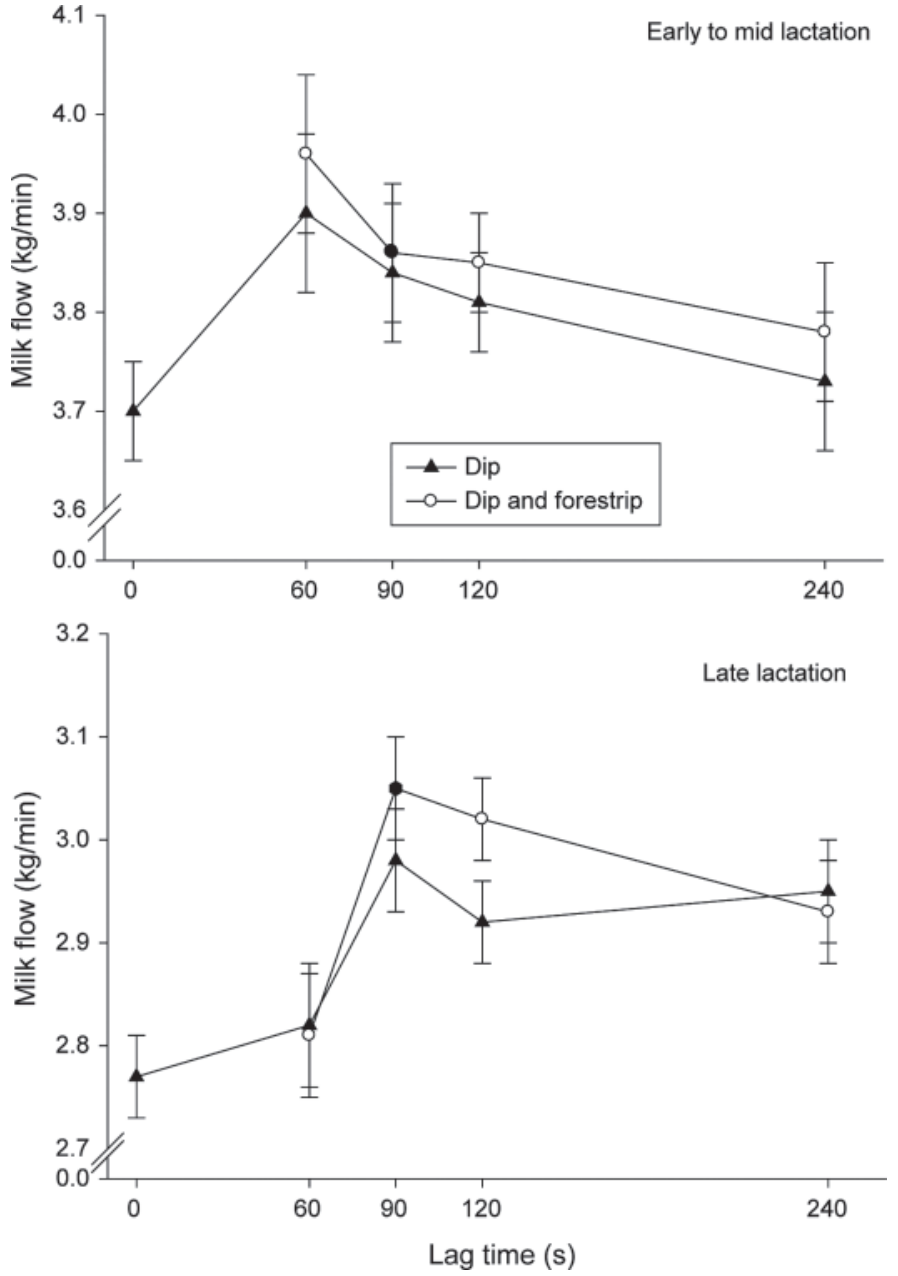

Figure 2. Milk flow rate $(\mathrm{kg} / \mathrm{min})$ for cows following a preparation procedure that involved predipping plus drying $(\mathrm{D}, \mathbf{\Delta})$ or predipping plus forestripping and drying $(\mathrm{DF}, \mathrm{O})$ with the comparison treatment (a preparation procedure involving predipping plus forestripping and drying with a lag time of $90 \mathrm{~s}$ (DF90, - for early to mid lactation cows (EML) and late-lactation (LL) cows. ${ }^{*} P<0.05$. 
Table 5. Percentage of total milk harvested during the first 2 min of milking unit on-time ${ }^{1}$

\begin{tabular}{|c|c|c|c|c|}
\hline \multirow[b]{2}{*}{$\operatorname{Lag}(\mathrm{s})$} & \multicolumn{2}{|c|}{ EML } & \multicolumn{2}{|c|}{ LL } \\
\hline & Dip + Dry & Dip + Forestrip & Dip + Dry & Dip + Forestrip \\
\hline 0 & $44.0^{\mathrm{a}}$ & & $44.7^{\mathrm{a}}$ & \\
\hline 60 & 52.5 & $55.8^{\mathrm{a}}$ & $55.2^{\mathrm{a}}$ & $53.1^{\mathrm{a}}$ \\
\hline 90 & 50.3 & 51.0 & $55.9^{\mathrm{a}}$ & 61.6 \\
\hline 120 & 51.7 & 52.8 & $57.3^{\mathrm{a}}$ & 61.3 \\
\hline 240 & 48.0 & 51.2 & $57.2^{\mathrm{a}}$ & $57.4^{\mathrm{a}}$ \\
\hline
\end{tabular}

${ }^{a}$ Comparisons were made against dip + forestrip with $90 \mathrm{~s}$ of lag time (DF90) and within stage of lactation, and treatments differed from DF90 at $P<0.05$.

${ }^{1}$ Stage of lactation: $\mathrm{EML}=$ early to mid lactation; $\mathrm{LL}=$ late lactation.

in the first 2 min. Reid and Stewart (2001) indicated that, across all cows, $57 \%$ of milk was harvested in the first $2 \mathrm{~min}$ on an 800-cow dairy. We found that 50 to $55 \%$ of milk was harvested in the first 2 min if lag time was $\geq 60 \mathrm{~s}$ and $<240 \mathrm{~s}$ for EML and that 53 to $61 \%$ of milk was harvested if lag time was $\geq 60 \mathrm{~s}$ for LL. The cisternal fraction of milk decreases from 18 to $13 \%$ when comparing mo 2 and 3 of lactation to mo 10 and 11 (Bruckmaier et al., 1994) and this may explain why the longer lag time showed a higher percentage of milk harvested in the first 2 min for LL cows.

The mean average flow $(\mathrm{kg} / \mathrm{min})$ for DF90 was $3.9 \pm$ 0.07 and $3.0 \pm 0.05$ for EML and LL cows, respectively (Figure 2). Average flow differed only for LL cows and, in those cows, only if the lag time was $<90 \mathrm{~s}$. Merrill et al. (1987) found that the average flow rate increased beyond wk 24 of lactation when a full premilking routine $(60 \mathrm{~s})$ was used instead of a minimal premilking routine (15 s). Wagner and Ruegg (2002) found that the milk flow rate was $0.36 \mathrm{~kg} / \mathrm{min}$ higher for highproducing cows compared with low-producing cows; the increase in flow rate with high-producing cows is in agreement with our study (the EML cows had a flow rate $0.9 \mathrm{~kg} / \mathrm{min}$ higher than LL cows). In contrast to our study, Wellnitz et al. (1999) found no difference between high-producing and low-producing cows (2.8 and $2.5 \mathrm{~kg} / \mathrm{min}$, respectively). The EML cows in our experiment produced $>45 \mathrm{~kg} / \mathrm{d}$, whereas the high-producing cows in the previously mentioned study produced 24 $\mathrm{kg} / \mathrm{d}$ (our low-producing LL cows produced $>30 \mathrm{~kg} / \mathrm{d}$ ); this overall higher production level in our study may explain why we saw differences in the flow rates, unlike the Wellnitz et al. (1999) study.

When analyzing the data for milking unit on-time and based solely on form of stimulation (and thus independent of lag time), the amount of time for complete milkout was essentially the same: $283 \mathrm{~s}$ (D) versus 279 $\mathrm{s}(\mathrm{DF})$ and $245 \mathrm{~s}(\mathrm{D})$ versus $242 \mathrm{~s}$ (DF) for EML and LL (Figure 3). When analyzing all data for milking unit on-time and based solely on lag time (thus independent of form of stimulation), no difference in treatments was

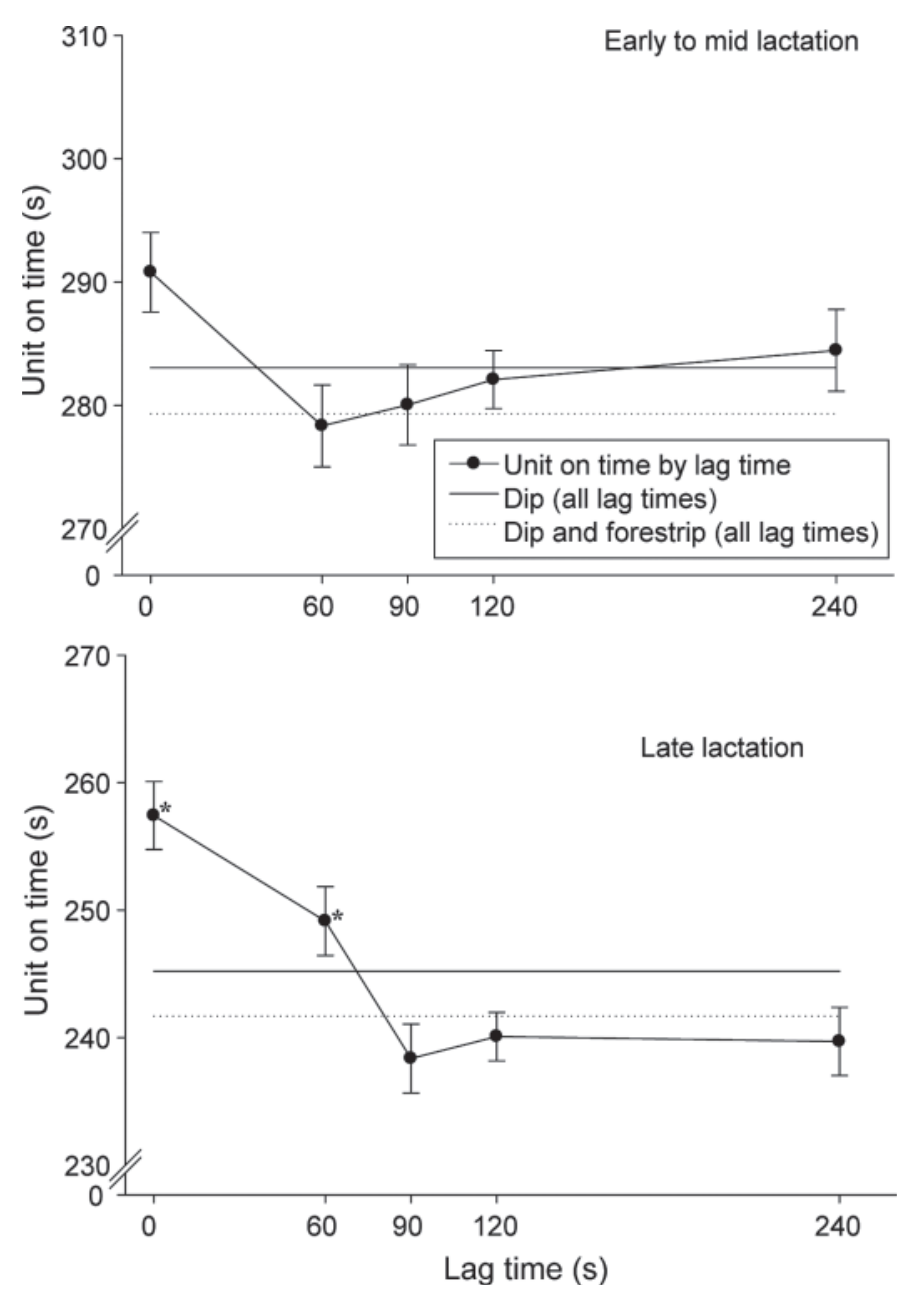

Figure 3. Milking unit on-time (s) for cows analyzed solely on lag time (and independent of form of stimulation) and for cows analyzed solely for form of stimulation (and independent of lag time). Early- to mid-lactation cows analyzed for lag time only $(\bullet)$ compared with a lag of $90 \mathrm{~s}$. Early to mid-lactation cows and predipping plus drying (-) compared with early- to mid-lactation cows and predipping plus forestripping and drying $(\cdots)$ and no lag time. Late-lactation cows analyzed for lag time only $(\bullet)$ compared with a lag of 90 s. Late-lactation cows and pre-dipping plus drying $(-)$ compared with late-lactation cows and predipping plus forestripping and drying $(\cdots)$ and no lag time. ${ }^{*} P<0.05$. 
observed compared with DF90 for EM cows; however, when lag time was $<90 \mathrm{~s}$, a significant difference $(P$ $<0.05$ for all treatments compared with DF90) was observed for LL cows (Figure 3). As lag time increased, the amount of time for complete milkout decreased for LL.

\section{CONCLUSIONS}

The interaction of forestripping or not forestripping with lag time had the greatest effect as indicated by the shortest milking unit on-times and the greatest amount of milk harvested in the first 2 min of milking. Late-lactation cows showed an increased benefit from a longer lag time as indicated by shorter unit ontime. Increasing the lag time beyond $60 \mathrm{~s}$ did not have a negative effect on EML cows. A greater effect on milking-time parameters, such as increased flow rates and decreased unit on-time, was seen for LL cows when lag time was increased beyond $60 \mathrm{~s}$ for high-producing Holstein cows milked 3 times daily.

\section{ACKNOWLEDGMENTS}

We thank GEA Farm Technologies (Bönen, Germany) for their financial support and guidance during the experiment. Special thanks to all the undergraduate research assistants from Cornell University for their help and support. Finally, thanks to Bergen Farms (Odessa, NY) for their support and assistance.

\section{REFERENCES}

Bava, L., A. Sandrucci, A. Tamburini, and G. Succi. 2005. Milk ejection during automatic milking in dairy cows. Ital. J. Anim. Sci. $4: 218-220$.

Bruckmaier, R. M., and J. W. Blum. 1996. Simultaneous recording of oxytocin release, milk ejection and milk flow during milking of dairy cows with and without prestimulation. J. Dairy Res. 63:201-208.

Bruckmaier, R. M., and J. W. Blum. 1998. Oxytocin release and milk removal in ruminants. J. Dairy Sci. 81:939-949.

Bruckmaier, R. M., E. Rothenanger, and J. W. Blum. 1994. Measurement of mammary-gland cistern size and determination of the cisternal milk fraction in dairy-cows. Milchwissenschaft 49:543-546.
Dodenhoff, J., D. Sprengel, J. Duda, and L. Dempfle. 1999. Potential use of parameters of the milk flow curve for genetic evaluation of milkability. Pages 131-141 in Proc. Int. Workshop on EU Concerted Action Genetic Improvement of Functional Traits in Cattle (GIFT); Breeding Goals and Selection Schemes. Bulletin No. 23. Wageningen Academic Publishers, Wageningen, the Netherlands.

Gorewit, R. C., and K. B. Gassman. 1985. Effects of duration of udder stimulation on milking dynamics and oxytocin release. J. Dairy Sci. 68:1813-1818.

Merrill, W. G., R. Sagi, L. G. Petersson, T. V. Bui, H. N. Erb, D. M. Galton, and R. Gates. 1987. Effects of premilking stimulation on complete lactation milk yield and milking performance. J. Dairy Sci. 70:1676-1684.

National Research Council. 2001. Nutrient Requirements of Dairy Cattle. 7th rev. ed. Natl. Acad. Press, Washington, DC.

Rasmussen, M. D., E. S. Frimer, D. M. Galton, and L. G. Petersson. 1992. The influence of premilking teat preparation and attachment delay on milk-yield and milking performance. J. Dairy Sci. 75:2131-2141.

Reid, D. A., and S. Stewart. 2001. Why unit on time is important for your dairy. Pages 13-16 in Proc. Proc 5th Western Dairy Management Conference, Las Vegas, NV. Western Dairy Management Conference, Manhattan, KS.

Reneau, J. K., and J. P. Chastain. 1995. Effect of cow prep on milk flow, quality and parlor throughput. Dairy Update 119, University of Minnesota Extension. Accessed Feb. 7, 2009. www.ansci.umn. edu/dairy/dairyupdates.htm.

Sagi, R., R. C. Gorewit, W. G. Merrill, and D. B. Wilson. 1980. Premilking stimulation effects on milking performance and oxytocin and prolactin-release in cows. J. Dairy Sci. 63:800-806.

Sandrucci, A., A. Tamburini, L. Bava, and M. Zucali. 2007. Factors affecting milk flow traits in dairy cows: Results of a field study. J. Dairy Sci. 90:1159-1167.

SAS Institute. 1999. User's Guide: Statistics. Version 8 ed. SAS Institute Inc., Cary, NC.

Smith, J. F., K. C. Dhuyvetter, M. J. VanBaale, D. V. Armstrong, and J. Harner. 2005. Managing the milking parlor: An economic consideration of profitability. Pages $165-180$ in Proc. NMC Annual Conference, Austin, TX. Natl. Mastitis Counc., Madison, WI.

Tancin, V., M. Uhrincat, L. Macuhova, and R. M. Bruckmaier. 2007. Effect of pre-stimulation on milk flow pattern and distribution of milk constituents at a quarter level. Czech J. Anim. Sci. 52:117121.

Wagner, A. M., and P. L. Ruegg. 2002. The effect of manual forestripping on milking performance of Holstein dairy cows. J. Dairy Sci. 85:804-809.

Weiss, D., and R. M. Bruckmaier. 2005. Optimization of individual prestimulation in dairy cows. J. Dairy Sci. 88:137-147.

Wellnitz, O., R. M. Bruckmaier, and J. W. Blum. 1999. Milk ejection and milk removal of single quarters in high yielding dairy cows. Milchwissenschaft 54:303-306. 